\title{
STRUCTURE OF PRONEPHROS AND DEVELOPMENT OF MESONEPHRIC KIDNEY IN LARVAE OF RUSSIAN STURGEON, ACIPENSER GUELDENSTAEDTII BRANDT (ACIPENSERIDAE)
}

\author{
L.S. Krayushinina*1, A.A. Gerasimov ${ }^{1}$, A.A. Kirsanov ${ }^{1}$, \\ M.V. Mosyagina ${ }^{1}$, A. OgorzateK ${ }^{2}$
}

\begin{abstract}
${ }^{1}$ Department of Ichthyology and Hydrobiology, St. Petersburg State University, 16-th Line 29, 199178, St. Petersburg, Russia, krayushkina@mail.ru

${ }^{2}$ Department of Animal Developmental Biology, Zoological Institute, University of Wroclaw, Sienkiewicza 21, 50-335 Wroclaw, Poland.

*Corresponding author
\end{abstract}

\begin{abstract}
The structure of the pronephros and development of mesonephric kidney in Russian sturgeon larvae, Acipenser gueldenstaedtii Brandt at different stages of early postembryonic development (from hatching to 14 days), were studied with histological and electronic microscopy methods. The larval pronephros is represented by the system of bilaterally located pronephric tubules with ciliated nephrostomes and funnels and exogenous single glomus, which is not integrated directly into pronephric tubules and located in the pronephric chamber. The glomus is positioned below the dorsal aorta and vascularized by its capillaries. The glomus has the same features of the thin structure that are typical of and necessary for the function of a filtering organ. The structure of the pronephros in acipenserids is discussed and compared with teleosts and amphibians. Histogenesis of the mesonephric kidney is observed during the period of pronephros functioning; it is complete by the time the larvae transfer to exogenous feeding. At this moment, the pronephros undergoes significant structural degradation.
\end{abstract}

Key words: pronephros, development of mesonephros, acipenserids, sturgeon larvae 


\section{INTRODUCTION}

Development of a number of organs and systems (circulatory, branchial, intestinal, etc.) in fish is completed through early stages of postembryogenesis. Despite considerable research into the larval period of fish, many areas related to its morphogenesis remain insufficiently studied. This also includes the structure of pronephros (the first kidney) and development of the mesonephric kidney in acipenserids.

As is known, the pronephros is the first kidney that is formed during embryonic development in all vertebrates; however, in fish and amphibians only the pronephros is retained after hatching of embryos (out of the ovum membrane) and represents the primary filtering and osmoregulatory organ in freeswimming larvae (Tytler 1988, Tytler et al. 1996, Vize et al. 1997). In fish, the pronephros is replaced during juvenile stages by the mesonephric kidney, whereas in other vertebrates the metanephric kidney is observed.

The teleost pronephros is a relatively simple organ. It is composed of a pair of nephrons with two glomeruli fused at the midline, pronephric tubules connecting directly to the glomeruli via a neck segment, and paired bilateral pronephric ducts, which convey the altered blood filtrate outside the animal. The glomeruli are vascularized by the capillaries of the superposed dorsal aorta. The pronephros in teleosts has no connection with the body cavity and it functions as a closed system (Tytler 1988, Tytler et al., 1996, Drummond et al., 1998).

Amphibians have a specific structure of the pronephros (Vize et al. 1997). The external glomus (vascularized filtration unit) is not integrated directly into the kidney tubule. The pronephric tubule and the glomus are formed on different sides of the coelom. The glomus is vascularized by the dorsal aorta, which spreads in the coelom. The waste fluid is filtered from the glomus into the coelom and is further taken into the branches of the pronephric tubule via thin ciliated funnels and the nephrostomes with fine cilia.

The organization of the pronephros in acipenserids (Chondrostei) demonstrates spatial patterning. The wax reconstruction of the pronephros at different developmental stages in lake sturgeon, Acipenser rubicundus (A. fulvescens, according to the modern fish taxonomy), based on serial histological sections, was presented by E. FrASER (1927). According to the data of the abovementioned works, morphology pattern of developed pronephros includes a system of pronephric renal tubules and the presence of elongated glomus lying in the pronephric chamber and non-integrated directly into the renal tubules. Since this publication (FRASER 1927), dedicated research of the pronephros structure in sturgeons has not been conducted.

However, this detailed and documented investigation of the pronephros in acipenserids made by E. Fraser (1927) has been overlooked in recent papers dedicated to the studies of early development in acipenserids, which offered the opinion of existence of aglomerular pronephros in acipenserids (DETLAF and Ginzburg 1954, Cataldi et al. 1999). 
The objective of this study was to examine sections of the pronephros and demonstrate the spatial organization of this organ in sturgeons. With reference to the earlier works, our paper attempts to follow-up the studies on pronephros morphology, in particular, its histological and ultrathin organization. Our results also include a detailed analysis of the replacement of the pronephros by the mesonephric kidney over the course of early postembryonic development of acipenserids.

\section{MATERIAL AND METHODS}

We studied the larvae of Russian sturgeon Acipenser gueldenstaedtii Brandt reared at a sturgeon hatchery in the Volga River delta. Newly-hatched larvae were placed in a tank with running river water and kept there for two weeks. Daily monitoring of optimum water conditions $\left(\mathrm{O}_{2}-7-8 \mathrm{mg} / \mathrm{L}, \mathrm{pH}-7.8\right.$ and water temperature $-18-19{ }^{\circ} \mathrm{C}$ ) were conducted using an "ANION-410D”oxygenmeter (Intrastack-Analit Company, St. Petersburg, Russia).

Larvae were sampled daily using fixations in neutral $4 \%$ formalin (study of general anatomy and development, entire specimens), in Bouin's Fixative, and Meves' fixative (for histological study). Conventional histological methods were used for this study. Histological sections were stained with azocarmine, according to the Heidenhain method (after Bouin's fixations), or iron hematoxylin, according to the Heidenhain method (after Meves' fixations) (RomeIs 1953).

Material for transmission electron microscopic (TEM) analysis was fixed for $24 \mathrm{~h}$ at $4{ }^{\circ} \mathrm{C}$ in modified Karnowsky's fixative: $\%$ paraformaldehyde (Sigma Aldrich), 2\% glutaraldehyde (Sigma Aldrich) in 0.15M phosphate buffer (pH 7.2). The samples were rinsed repeatedly in the same buffer and post-fixed for $2 \mathrm{~h}$ in $1 \% \mathrm{OsO}_{4}$ (Sigma Aldrich) in phosphate buffer. Following the rinsing in phosphate buffer, samples were dehydrated in graded alcohol series and acetone, and further embedded in epoxy resin Epon 812 (Sigma Aldrich). Epon blocks were cut on Reichert Ultracut E ultramicrotome. Semithin sections $(0.6 \mu \mathrm{m})$ were stained with methylene blue in $1 \%$ borax solution (Sigma Aldrich) and examined under a light microscope. Ultrathin sections were contrasted with uranyl acetate and lead citrate, according to the standard REynolds (1963) protocol, and examined by TEM, Zeiss EM 900 at an accelerating voltage of $80 \mathrm{kV}$.

Histological specimens were prepared at the Department of Ichthyology and Hydrobiology, St. Petersburg State University. Processing samples for electron microscopy study, as well as viewing ultrathin sections with the electron microscope and photography were performed at the Department of Animal Developmental Biology, University of Wroclaw, Poland.

\section{RESULTS}

In newly-hatched larvae, the pronephros is presented as a bilaterally positioned system of pronephric tubules and the glomus. On each side of the body, the system is set with six short pronephric tubules. They (except for the 
first pair) open into the collecting canal, which evolves into the excretory canal (pronephric duct) draining into the external environment. A typical loop is formed at the point, where the collecting canal transforms into the excretory canal; this loop is clearly visible externally on the surface of the dorsal part of the yolk sac. The posterior end of the first pronephric tubule opens instead into the lateral wall of the second pronephric tubule. The first pronephric tubule has two nephrostomes each opening into the expanded part of the coelomic cavity via the ciliated funnel. Epithelial cells of the nephrostomes have cilia as well (Figs. 1,2). The anterior ends of the other five pairs of pronephric tubules have their own funneled nephrostomes, each opening into the cavity of a separate pronephric chamber. Both nephrostomes and their funnels are ciliated (Fig. 3). Immediately after larval hatching, the cells of pronephric tubules and collecting canal contain a large amount of yolk granules (Fig. 2), which are further utilized and disappear in 2-3 days.

The wall of the nephrostome is lined with a one-layered epithelium with characteristic long cilia on the apical surface of the epithelial cells (Fig. 4a). These cilia are oriented in the direction of the nephrostome cavity. The cells have a well-developed tubular system of endoplasmic reticulum. The tubules are

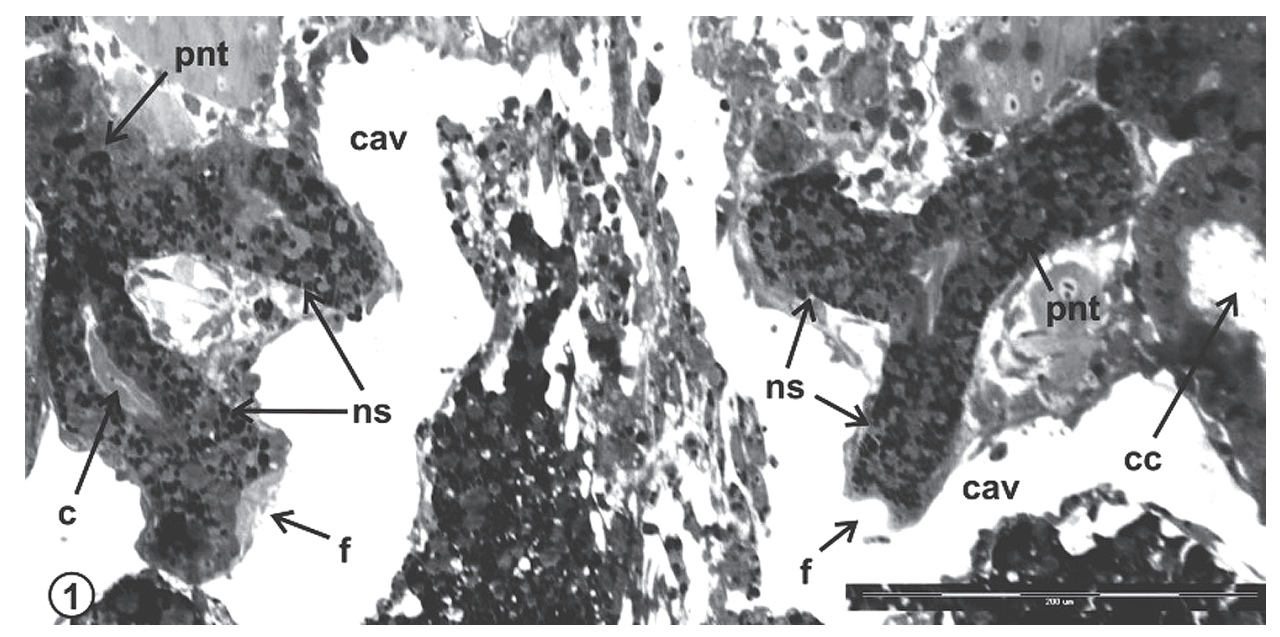

Fig. 1. The first pair of pronephric tubules on the left and right side of the body in larva of Russian sturgeon one day after hatching (length $10.3 \mathrm{~mm}$ ). Each tubule has two ciliated nephrostomes with funnels opening into the expanded part of the coelom cavity. Semithin tangental section stained with methylene blue. Ob. 10X, oc. 7X pnt - pronephric tubule; ns - nephrostome; c - cilia in the nephrostome; $\mathrm{f}$ - ciliated funnel; cc - collection canal; cav - coelomic cavity. 


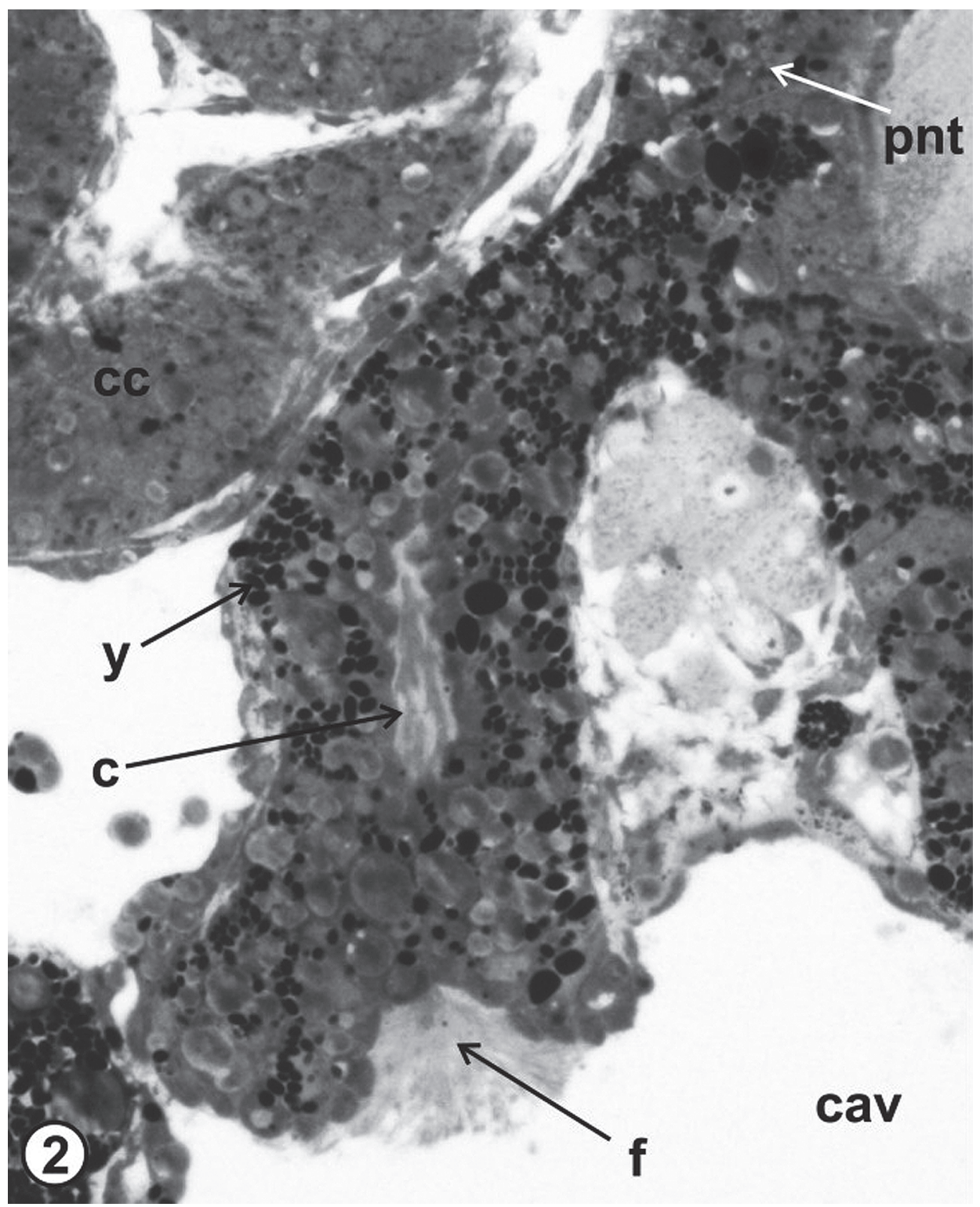

Fig. 2. The nephrostome of the first left-side pronephric tubule (shown in Fig.1). Semithin tangental section stained with methylene blue. Ob. 20X, oc. 10X. y - yolk granules. 


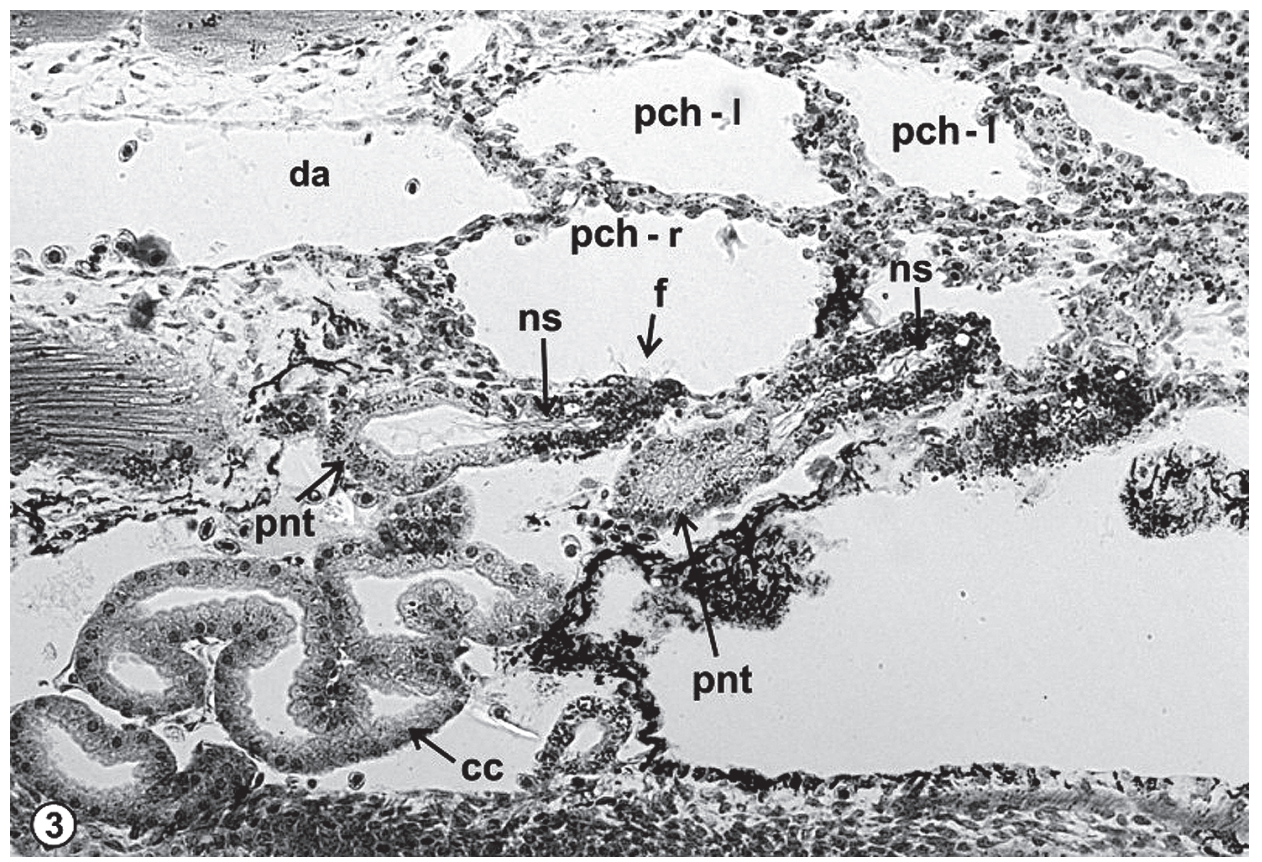

Fig. 3. The pronephric tubules opening into the pronephric chambers in the larva of Russian sturgeon one day after hatching (length $10.3 \mathrm{~mm}$ ).

Histological sagittal section stained with Heidenhain's azocarmine. Ob. 10X, oc. 10X. pch-1 - pronephric chambers on the left body side; pch-r - pronephric chambers on the right body side; da - dorsal aorta.

arranged in a basolateral direction with mitochondria in close proximity along their length. The cytoplasm contains numerous free ribosomes. The intercellular spaces are dilated (Fig.4b).

The walls of collecting and excretory canals are lined with a one-layered epithelium, too. The nuclei are confined to the basal part of cells. The cytoplasm in the apical side of epithelial cells of the collecting canal is vacuolated.

Over the course of larval development, the lateral walls between pronephric chambers become degraded, leading to the formation of a single pronephric chamber where the glomus is situated. Localization of the pronephric glomus was identified from histological cross-sections taken from larvae aged four and seven days post-hatching, which have already formed a single pronephric chamber. 


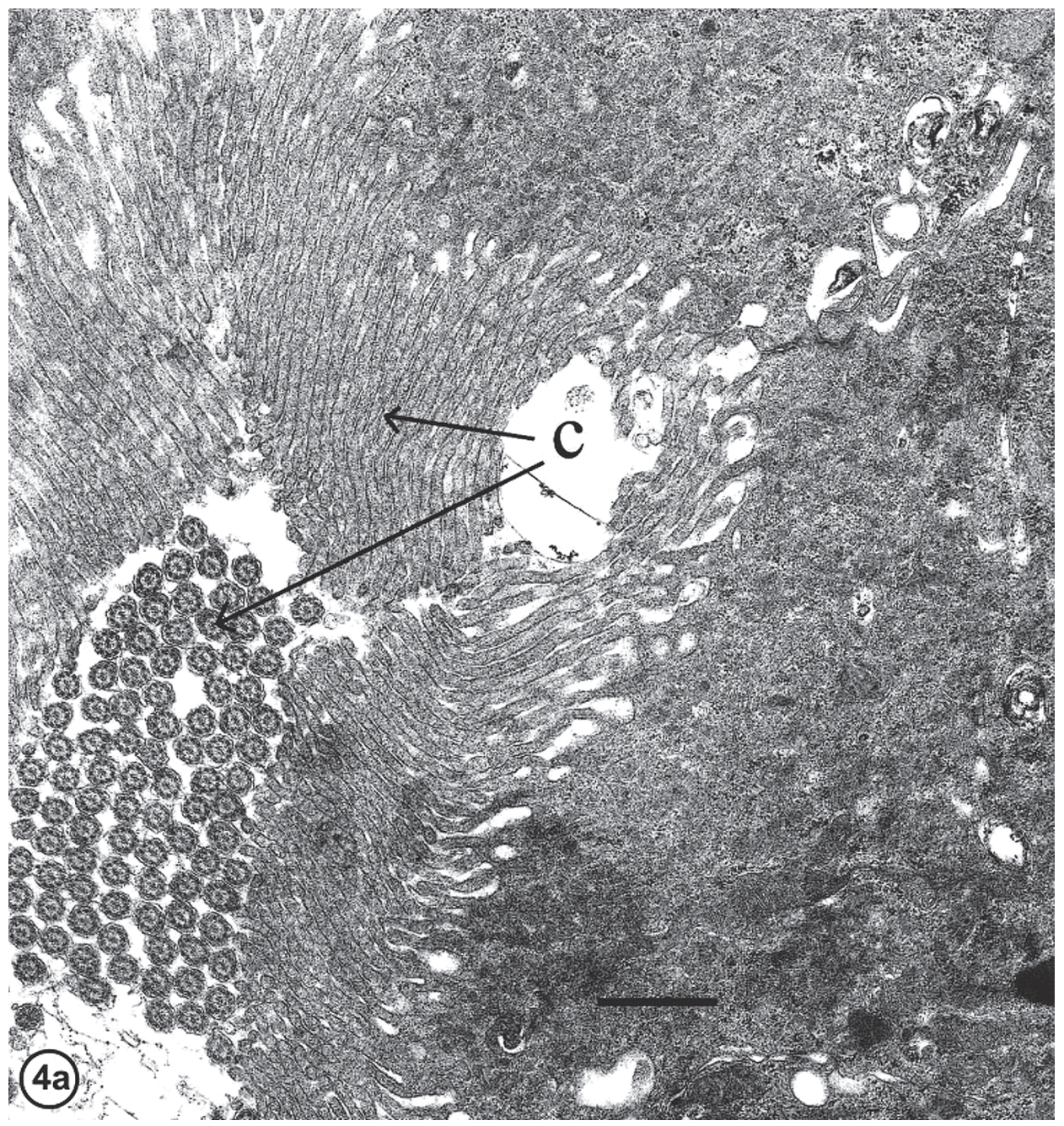

Fig. 4a. Epithelial cell of the nephrostome of the first pronephric in the larva of Russian sturgeonone day after hatching (length $10.3 \mathrm{~mm}$ ). Scale bar. $1.1 \mu \mathrm{m}$ Apical part of the cell having the cilia (c). 


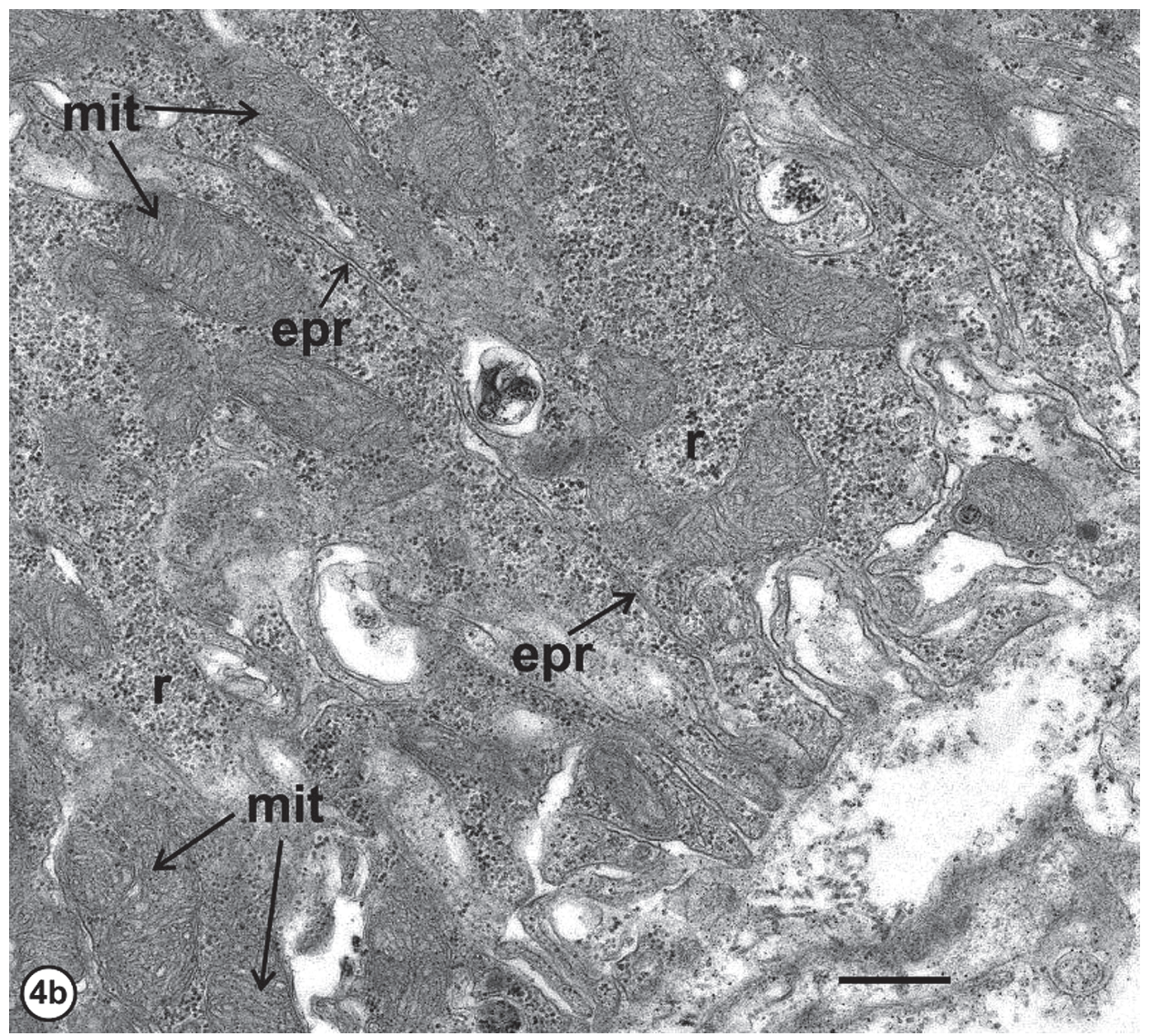

Fig. 4b. Epithelial cell of the nephrostome of the first pronephric in the larva of Russian sturgeonone day after hatching (length $10.3 \mathrm{~mm}$ ). Scale bar. $1.1 \mu \mathrm{m}$.

Basal part of the cell.

mit - mitochondria; epr - the tubules of endoplasmatic reticulum; $r$ - ribosomes.

The glomus is located at the dorsal wall of the pronephric chamber, closely adheres to the dorsal aorta and is vascularized by its capillaries. The dorsal aorta lies immediately below the chord. Pronephric tubules approach the pronephric chamber and open into the chamber cavity via the funnels of ciliated nephrostomes (Fig. 5, 6).

The fine structure of the glomus is pierced with a large number of capillaries. The capillary endothelium features numerous pores. Podocytes are situated around capillaries' walls. In contact areas, the podocytes develop foot processes (pedicels) which rest on the capillary walls. The podocyte cytoplasm includes a moderate amount of mitochondria, lysosomes, and cisterns of endoplasmic reticulum, as well as cell-specific filaments. There are mesanglial cells in the structure of the glomus (Fig. 7, 8a, 8b). 


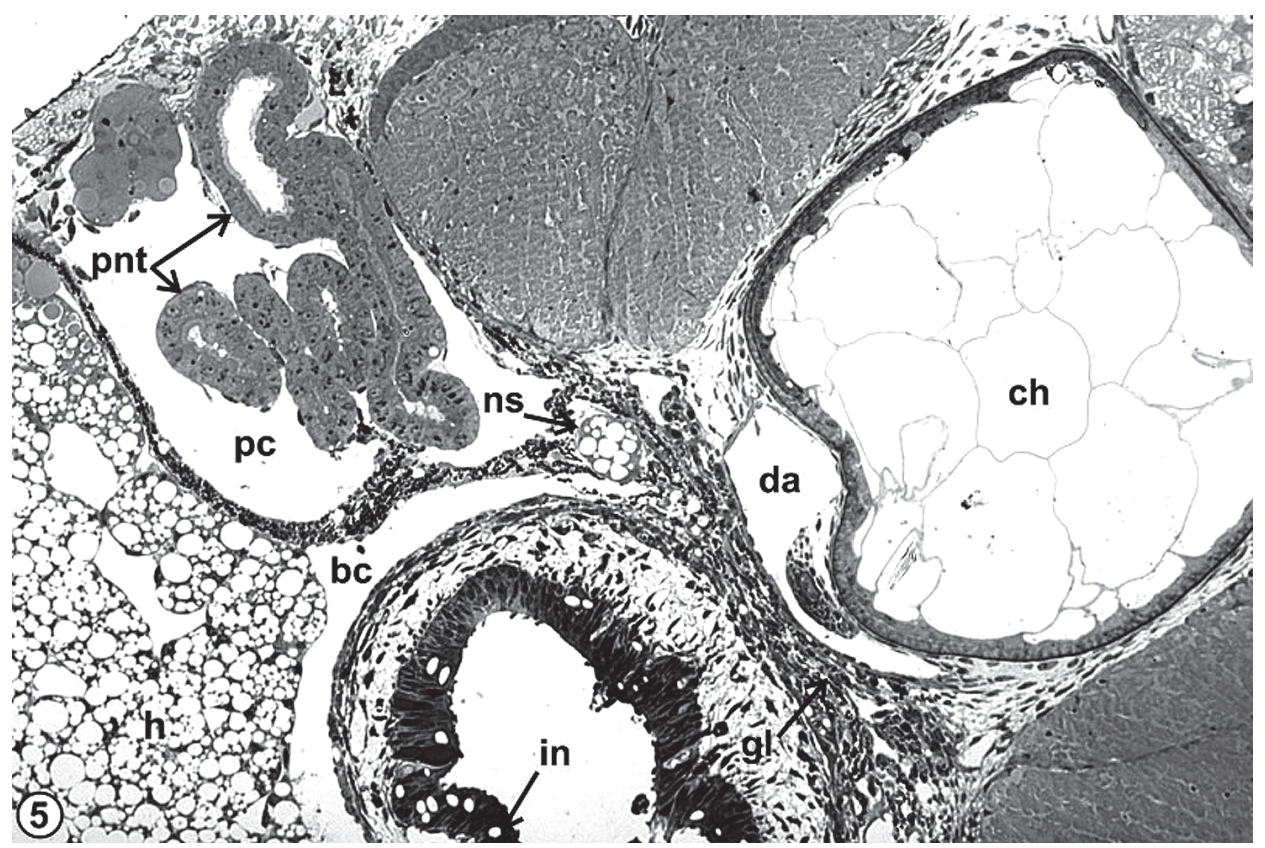

Fig. 5. Semithin transversal section in the larva of Russian sturgeon four days after hatching (length $5.5 \mathrm{~mm}$ ). The cut is made on the level of the oesophagus and the anterior edge of the liver. Ob. 10X, oc. 10X.

ch - chorda; da - dorsal aorta; gl - glomus; pc - cavity of pronephric chamber; pnt pronephric tubules; ns - nephrostomes; bc - body cavity; in - oesophagus; $h$ - liver.

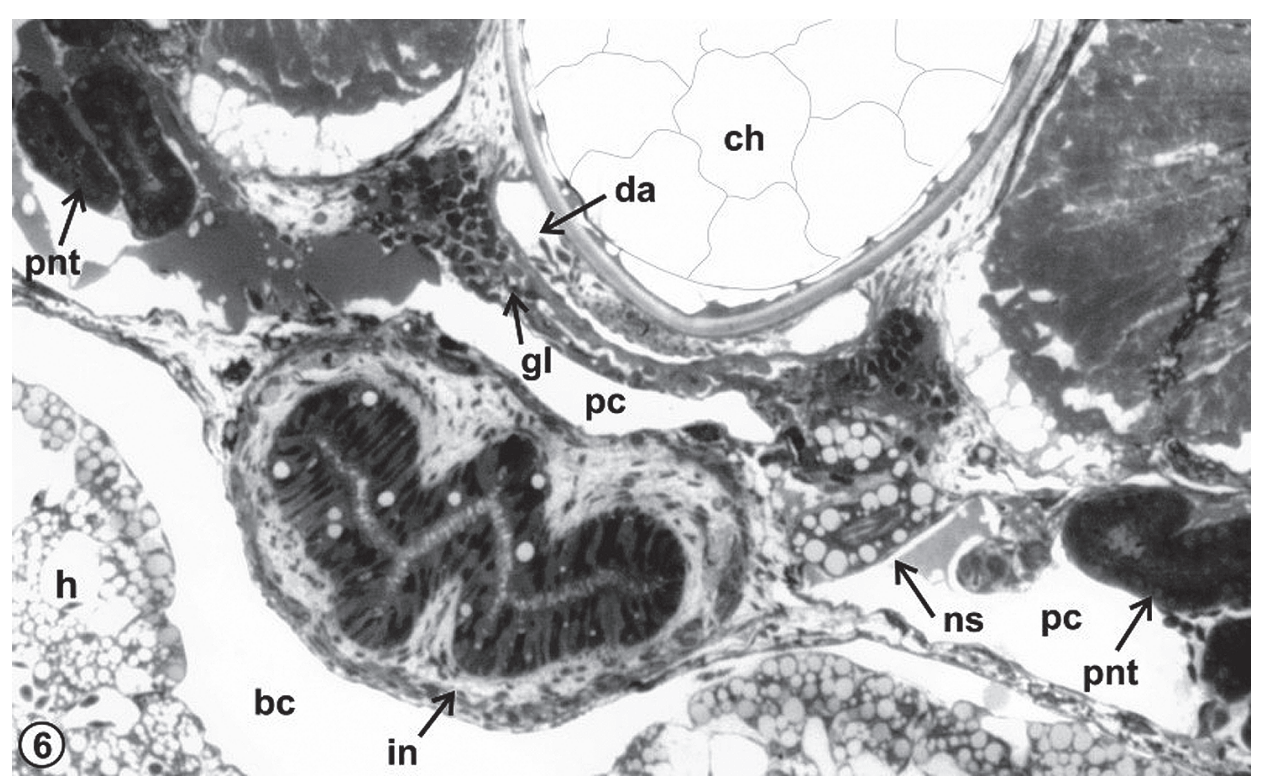

Fig. 6. Semithin transversal section. in the larva of Russian sturgeon seven days after hatching (length $20 \mathrm{~mm}$ ). The cut is made on the level of the oesophagus and the anterior edge of the liver. Ob. 10X, oc. 10X. 


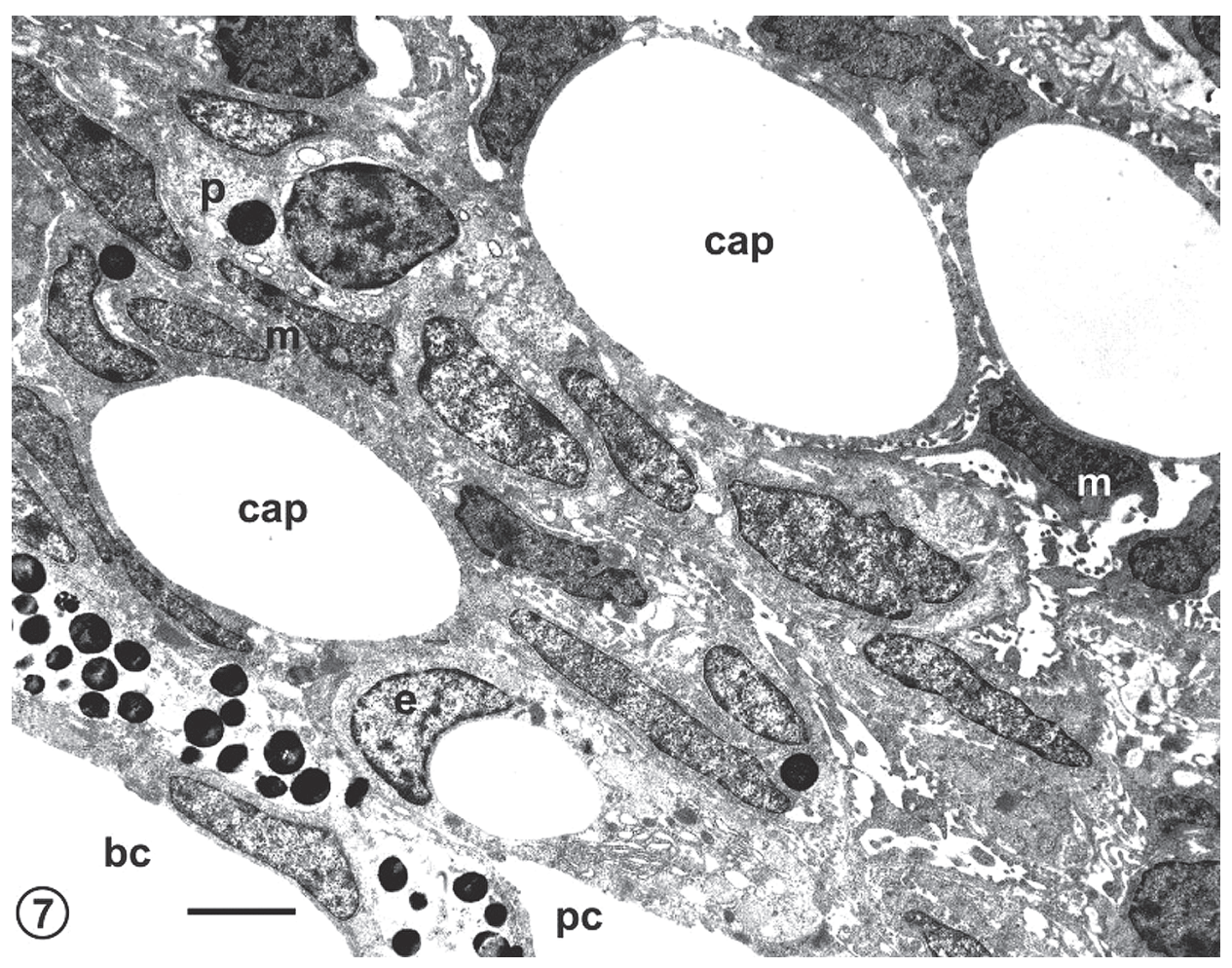

Fig. 7. Ultrathin cross section (fragment) of the glomus. Russian sturgeon larva seven days after hatching. (length $20 \mathrm{~mm}$ ).

Transversal section. Scale bar $2.5 \mu \mathrm{m}$.

cap - capillary; m - mesanglial cell; pc - cavity of pronephric chamber; bc - cavity of body.

The pronephros structure in larvae retains its integrity until they reach 8 10 days age (the average length of larvae is $23-25 \mathrm{~mm}$ ) and after that the pronephros undergoes gradual degradation. Signs of destruction are revealed, primarily, in the fine structure of renal tubules and funneled nephrostomes. These elements become considerably degenerated in 12 days old larvae (average body length $-27 \mathrm{~mm}$ ) but the collecting canals still remain.

Formation of the mesonephric kidney occurs concurrently with the functioning of the pronephros. Immediately after hatching, larvae have a mesodermal band (located close to the pronephric duct and oriented along its course) in the process of morphological differentiation into primordial structures of the mesonephric kidney. Part of these primordia are connected with the residual mesodermal band. On the third day after hatching (average larval length $-14.9 \mathrm{~mm}$ ), the primordial mesonephric tubules are well isolated and present with rounded 


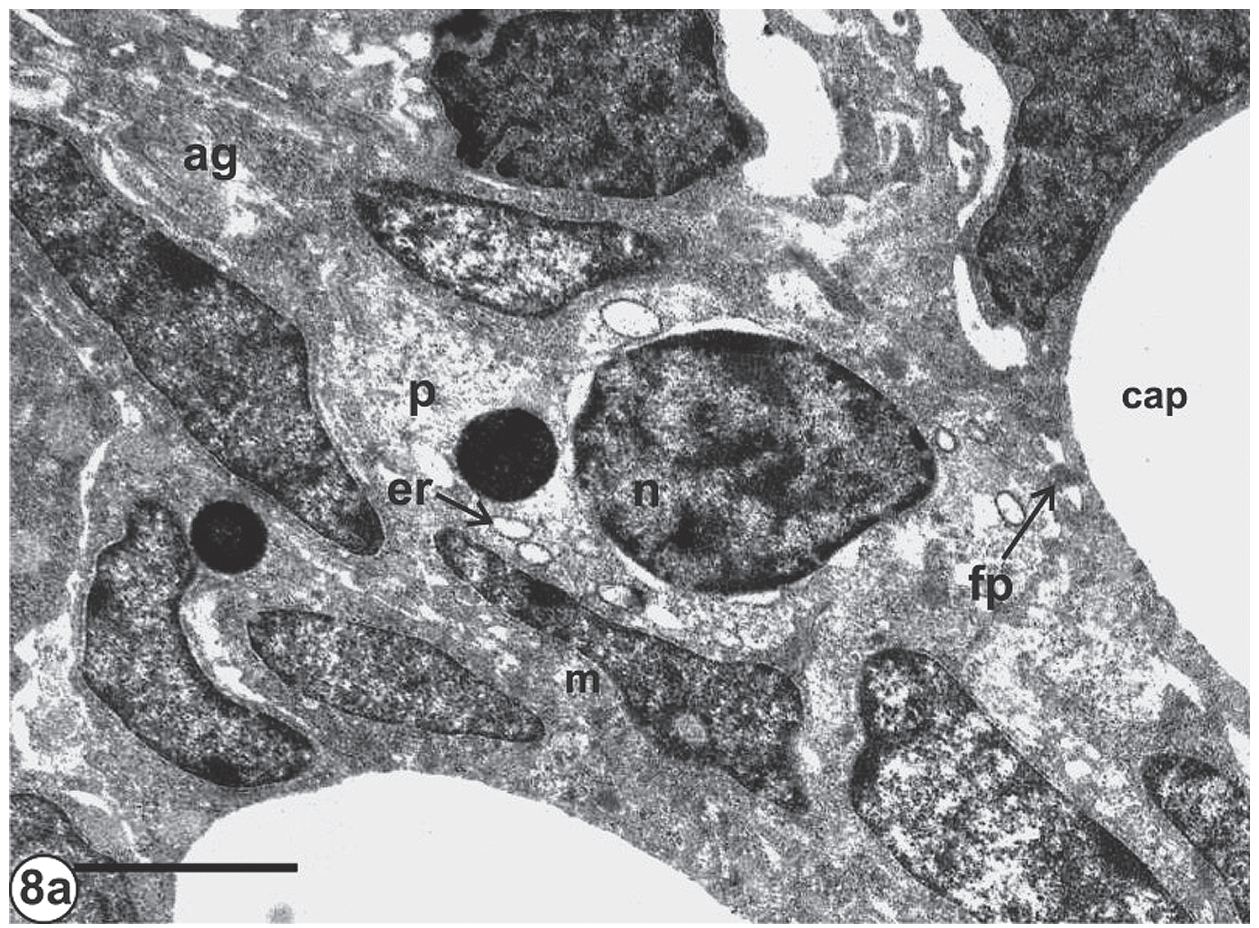

Fig. 8a. Details of Fig. 7.

Podocytes with the foot processes leaning on the endothelium of the capillary. Scale bar $2.5 \mu \mathrm{m}$.

$\mathrm{p}$ - podocyte; $\mathrm{n}$ - nucleus; fp - foot processes; cap - capillary; er - cisterns of endoplasmic reticulum; ag - Golgi apparatus; $\mathrm{m}$ - mesanglial cell.

cell clusters with an incipient inside cavity (Fig. 9). By the fourth day posthatching (average larval length $-15.8 \mathrm{~mm}$ ), the tubular cavity becomes more pronounced, the primordial tubules become longer and acquire slightly narrowing pattern. Primordial glomeruli appear near the tubules (Fig. 10). By the fifth day post-hatching (average larvae length $-17 \mathrm{~mm}$ ), the developing tubules join the pronephric duct. During their growth, mesonephric tubules take on a convoluted shape. Glomeruli form by the sixth day post-hatching (average larval length - 18-19 $\mathrm{mm}$ ), when the main elements of the circulatory system appear and larvae depend completely on gill respiration and mixed (yolk and exogenous food) feeding (Fig. 11). Further development demonstrates an increase in their size. Thus, by the twelfth day (average larval length $-27 \mathrm{~mm}$ ), when the ultrastructure of the pronephric renal tubules becomes largely degenerated, the mesonephric kidney is well developed and replaces the pronephros. By this time, larvae are fully dependent on exogenous feeding. 


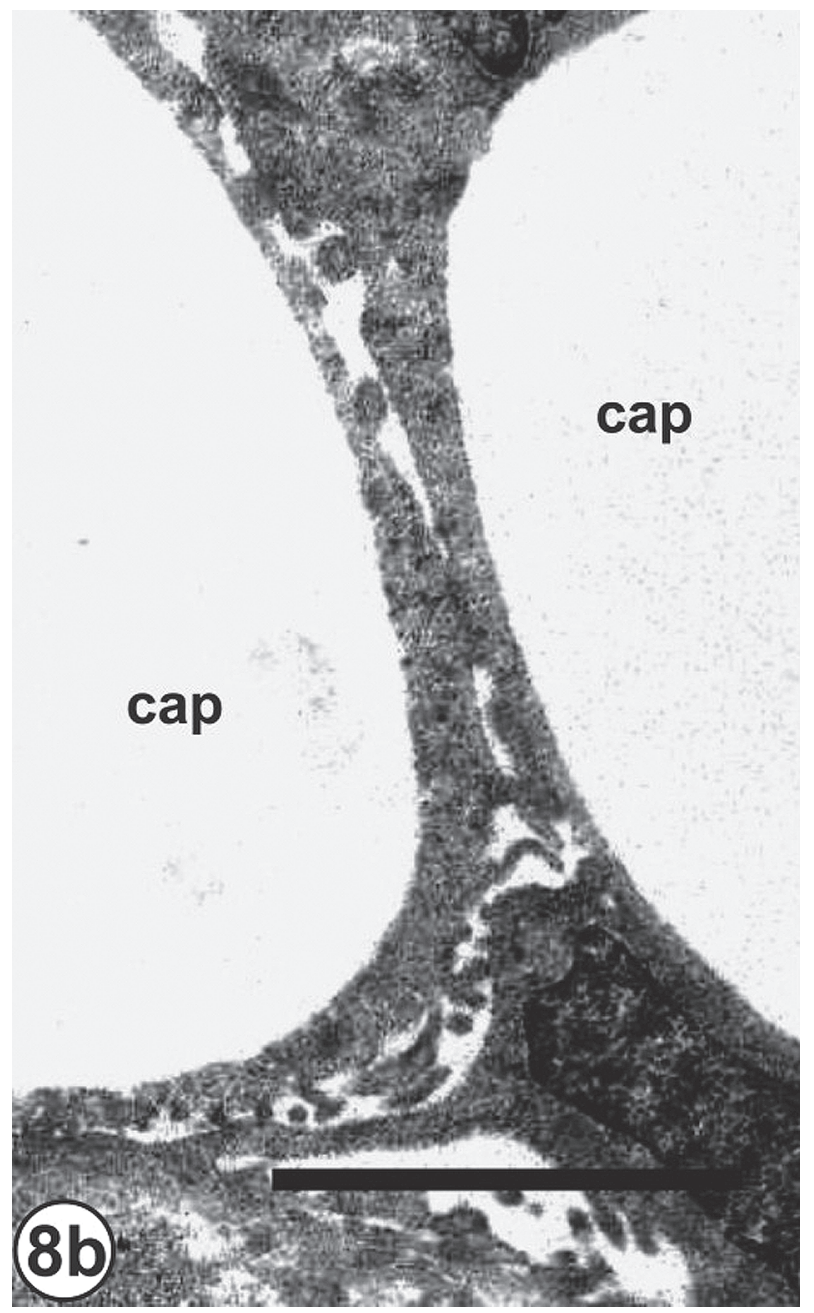

Fig. 8b. Details of Fig. 7

Endothelium of the capillary.

Scale bar $2.5 \mu \mathrm{m}$. 


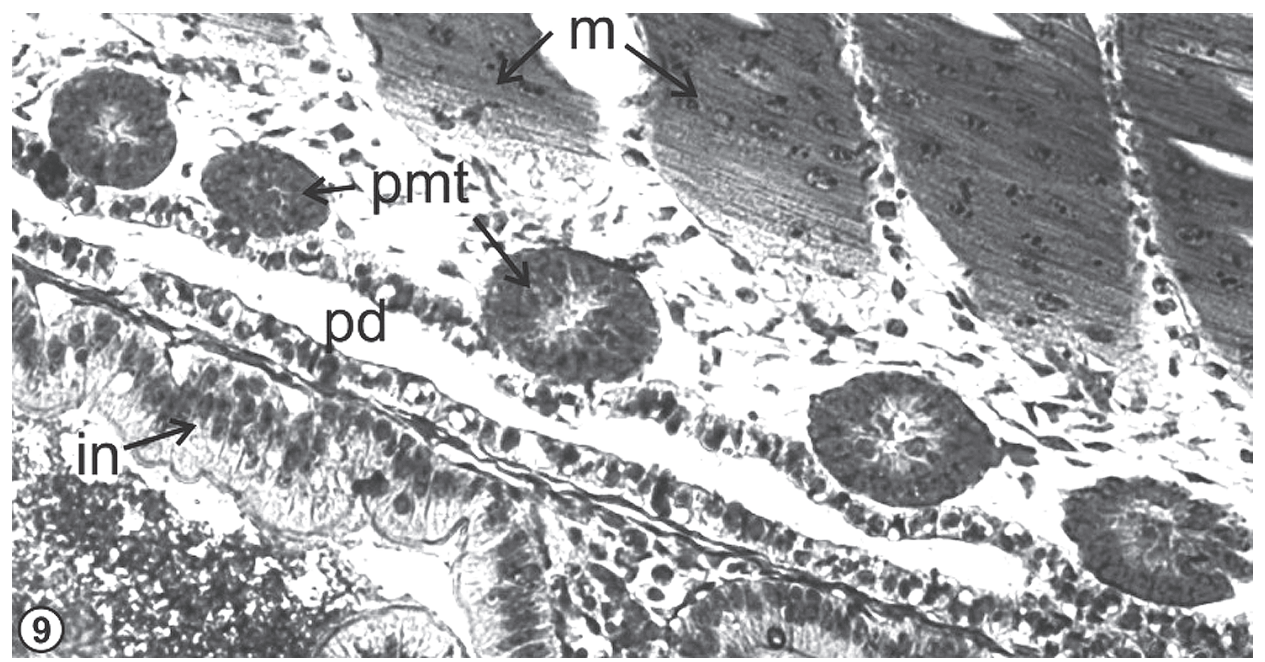

Fig. 9. The primordia of mesonephric tubules (pmt) arising along the pronephric duct (pd) in the larva of Russian sturgeon three days after hatching (length14.9 $\mathrm{mm}$ ). Histological sagittal section stained with Heidenhain's azocarmine.

Ob. 20X, oc. 10X. m - muscles; in - intestine.

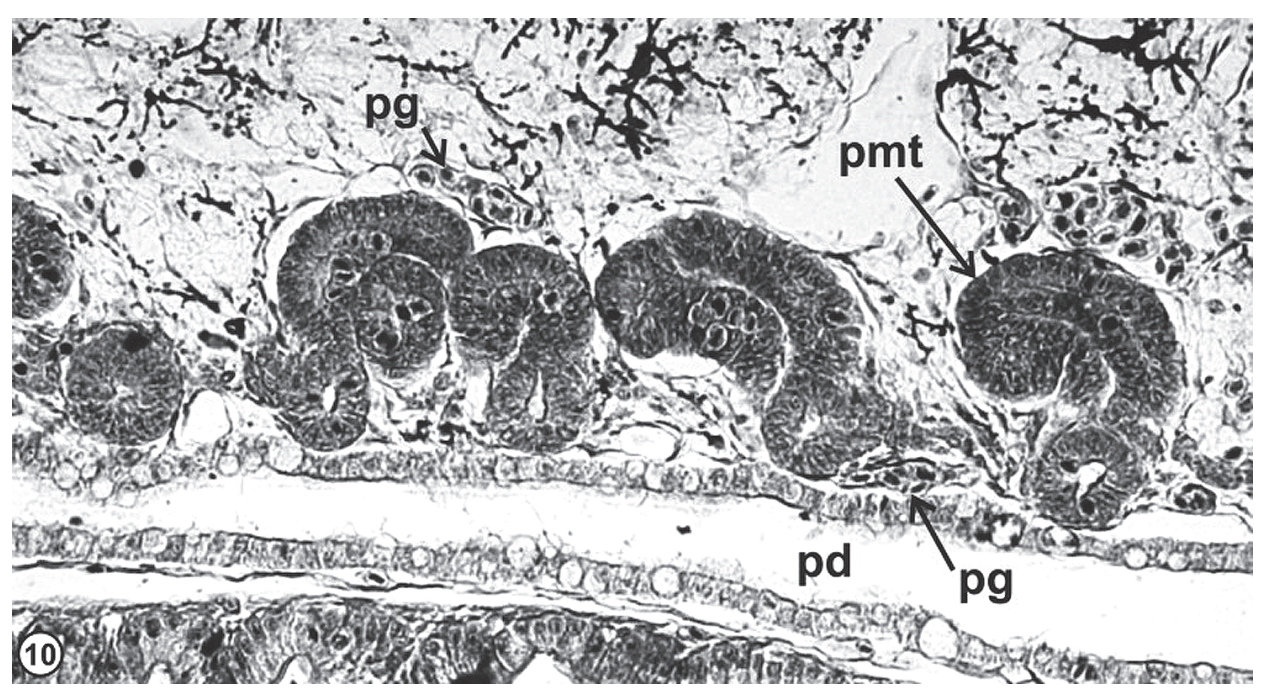

Fig. 10. The primordia of mesonephric tubules (pmt) and the glomeruli (pg) in the larva of Russian sturgeon four days after hatching (length $15.8 \mathrm{~mm}$ ).

Histological sagittal section stained with Heidenhain's iron hematoxylin. Ob. $20 \mathrm{X}$, oc. $10 \mathrm{X}$. pd - pronephric duct. 


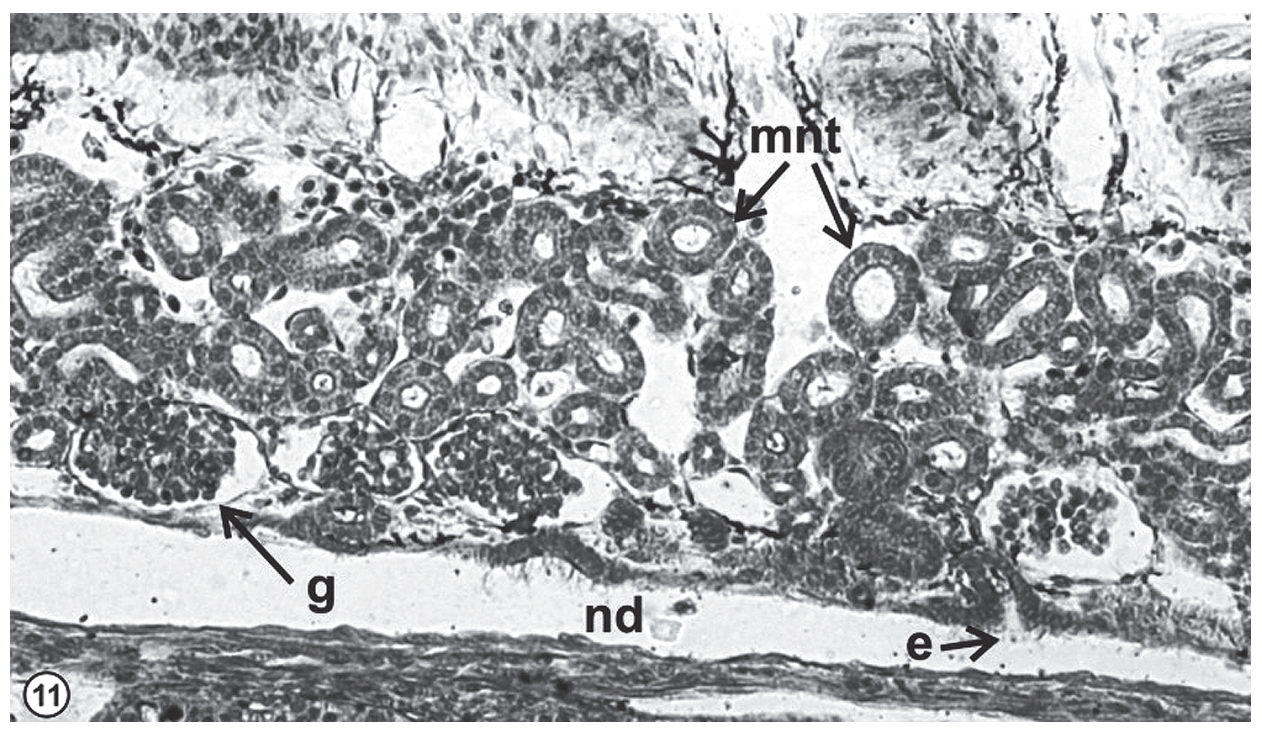

Fig. 11. The mesonephric kidney in the larva of Russian sturgeon four days after hatching (length $18.5 \mathrm{~mm}$ ). Histological sagittal section stained with Heidenhain's azocarmine. Ob. $10 \mathrm{X}$, oc. $10 \mathrm{X}$.

$\mathrm{mnt}$ - mesonephric tubules; $\mathrm{g}$ - glomerule; e - exit of mesonephric tubule into the nephric duct (nd).

\section{DISCUSSION}

Our study investigated features of the pronephros structure in Russian sturgeon at early stages of post-embryonic development (from hatching to 14 days). Histological and fine structure of the individual components of the pronephric system were described. The presented work represents the first work to further development into research of the pronephros in sturgeons since publication of the study conducted by Fraser (FRASER 1927), which is needed for a better understanding of the specifics of this provisional organ in chondrosteans.

Obtained data are concurrent with the general plan of sturgeon pronephros morphology and confirm its complex pattern, as described earlier for the lake sturgeon (FRASER 1927). The key morphological feature of sturgeon pronephros is the presence of single elongated glomus (filtering organ) lying in the pronephric chamber and the bilateral system of pronephric tubules opening into the chamber (except for the first pair, which open into the expanded coelomic cavity). The glomus in sturgeon is not directly integrated into the system of renal tubules but extends freely into the pronephric chamber.

Therefore, the results of this work argue against the erroneous statement about the presence of aglomerular pronephros in acipenserids (DetLAF and GinzBurg 1954, CATAldi et al. 1999). It should also be noted that the abovementioned papers were not focused specifically on the pronephros structure and were largely dedicated to general characteristics of embryonic and post-embryonic 
development of sturgeons. Moreover, the authors conclusion in regard to aglomerular kidney in sturgeon larvae was not documented.

Our study serves to improve the state of knowledge on the structural features of pronephros in sturgeons. As opposed to the mentioned description of pronephric tubules (Fraser 1927, Detlaf and Ginzburg 1954), we identified the fact that each of the first pronephric tubules has two contiguous nephrostomes opening into the expanded part of the coelom via the funnel.

The glomus is located below the dorsal aorta and is vascularized by its capillaries. It has the same fine features that are characteristic of and necessary for the functions of a filtering organ, similar to the described glomeruli in teleost larvae (Drummond et al. 1998) and the glomus in cyclostomes (KLUGE and FisCHER, 1990). These include capillaries with endothelial pores, podocytes with foot processes (pedicles) resting on capillary walls, and mesanglial cells. Thus, the glomus structure in sturgeons reveal the presence of all cellular elements indicative of the filtering functions of this organ.

The pronephros structure allows for the suggested pattern of its functioning, as follows. The glomus filters the primary urine into the pronephric cavity where it is pumped via ciliated nephrostome funnels into the renal tubules. The composition of primary urine in the renal tubules changes, due to secretory and sorption processes occurring in vertebrates, and the modified filtrate is drained into the external environment.

A description of the detailed structure of the pronephros in acipenserids enables us to compare it with the pronephros of teleosts and amphibians. Anatomical organization of the pronephros in acipenserids differs significantly from that of teleosts (Tytler 1988, Tytler et al. 1996, Drummond et al. 1998). The pronephros of teleosts has no connection with the body cavity and it functions as a closed system. Unlike the teleosts, the pronephros in sturgeons does not form a closed system, since the glomus lies freely in the pronephric chamber and has no direct connection with pronephric tubules. The filtrate produced by the glomus is transported from the pronephric chamber via the funneled nephrostomes of the tubular system. This important feature represents certain convergence between acipenserids and amphibians. Amphibians have a specific structure of the pronephros (Vize et al. 1997). The external glomus (vascularized filtration unit) is not integrated directly into the kidney tubule. Similar to amphibians, pronephric tubules in sturgeons possess nephrostomes that open into the coelom via funnels. However, the number of pronephric tubules in sturgeons is higher than that in amphibians. Obviously, the transport of fluids from the coelom to pronephric tubules is directed by undulating movements of cilia, the same as in amphibian larvae.

The mesonephric kidney in sturgeons develops during the period of functional pronephros. Its histogenesis is complete by the time the larvae transfer to exogenous feeding. At this time, the pronephros becomes significantly degraded.

\section{Acknowledgments}

This work was supported by the Russian Fund of Basic Investigation (a 08-04-01006) and in part by a State Committee for Scientific Research grant from the University of Wroclaw, Poland. We are grateful to Professor Janusz Kubrakiewicz, 
the head of the Department of Animal Developmental Biology, University of Wrocław, for facilitating the electron microscopy study, as well as Katarzyna Payer and SylwiA NowAK, members of this Department, for their technical assistance.

\section{STRUKTURA PRZEDNERCZA I ROZWÓJ ŚRÓDNERCZA U LARW JESIOTRA ROSYJSKIEGO ACIPENSER GUELDENSTAEDTII BRANDT (ACIPENSERIDAE).}

\section{STRESZCZENIE}

Badania histologiczne w połączeniu z metodami mikroskopii elektronowej posłużyły do badań struktury przednercza (pronephros) i rozwoju śródnercza (mesonephros) larw jesiotra rosyjskiego Acipenser gueldenstaedtii Brandt w różnych fazach rozwoju postembrionalnego (od wylęgu do larwy 14-dniowej). Szczegółowo opisana i udokumentowana serią zdjęć mikroskopowych struktura pronephros u tego przedstawiciela rodziny jesiotrowatych posłużyła do porównania z analogicznymi narządami u ryb kostnych (Teleostei) i u płazów oraz do szerszej dyskusji tego zagadnienia. Histogeneza mesonephros została zaobserwowana podczas funkcjonowania przednercza; jej zakończenie jest zsynchronizowane z czasem przejścia larwy na samodzielne odżywianie zewnętrzne. Od tego momentu przednercze wchodzi w proces systematycznej degradacji.

\section{REFERENCES}

Cataldi E., Barzaghi C., Di Marco P., Boglione C., Dini L., Mckennzie D.J., Bronzi P., Cataudella S. 1999: Some aspects of osmotic regulation in Adriatic sturgeon Acipenser naccarii. I: Ontogenesis of salinity tolerance. J. Appl. Ichthyol., 15 (4-5): 57-60.

Detlaf T.A., Ginsbourg A.S. 1954: Primordial development of acipenserids (starred sturgeon, Black Sea sturgeon, great sturgeon) in connection with questions of their reproduction. Moscow. Press of Academy of Sciences of USSR, $216 \mathrm{pp}$. (in Russian).

Dummond I.A., Majumdar A., Hentschel H., Elger M., Solnica-Krezel L. et al., 1998: Early development of the zebrafish pronephros and analysis of mutations affecting pronephric function. Development, 125: 4655-4667.

Kluge B., Fischer A. 1990: The pronephros of the early ammocoete larva of lampreys (Cyclostomata, Petromyzontes): Fine structure of the external glomus. Cell. Tss. Res. 260: 249-259.

Reynolds E.S. 1963: The use of lead citrate at high $\mathrm{pH}$ bas an electron-opaque stain in electron microscope. J. Cell Biol., 17, 208-12.

Romeys B. 1953: Microscopic technique (Translated by Russian. Ed. I.I. Sokolov)// Moscow: Foreign literature. 718 pp. (in Russian)

Tytlen P. 1988: Morphology of the pronephros of the juvenile brown trout, Salmo trutta. J. Morphol., 195: 189-204.

Tytler P., Ireland J., Fitches E. 1996: A study of the structure and function of the pronephros in the larvae of the turbot (Scophthalmus maximus) and the herring (Clupea harengus). Mar. Fresh. Behav. Physiol., 28: 3-18.

Vize P.D., Seufert D.W., Caroll, T.J., Wallingford J.B. 1997: Model system for the study of kidney development: use of the pronephros in the analysis of organ induction and patterning. Dev. Biol., 188: 189-204. 